\title{
Improvement of solar still productivity by using PCM and other enhancement technique- $A$ review
}

\author{
Abhinav Yadav ${ }^{1 *}$, Md Saifullah Khalid ${ }^{2}$, Prashant Saini ${ }^{3}$, Ankit Kumar ${ }^{4}$ \\ ${ }^{I^{*}}$ Department of Mechanical Engineering, Madan Mohan Malaviya University of Technology (Uttar Pradesh State University) Gorakhpur, INDIA \\ ${ }^{2}$ Department of Mechanical Engineering, Madan Mohan Malaviya University of Technology (Uttar Pradesh State University) Gorakhpur, INDIA \\ ${ }^{3}$ Department of Mechanical Engineering, Madan Mohan Malaviya University of Technology (Uttar Pradesh State University) Gorakhpur, INDIA \\ ${ }^{4}$ Department of Mechanical Engineering, Madan Mohan Malaviya University of Technology (Uttar Pradesh State University) Gorakhpur, INDIA \\ "Corresponding Author: e-mail: ${ }^{1 *}$ abhinavyadavgzp10@gmail.com \\ ${ }^{2}$ mdsaifkhush@gmail.com
}

\begin{abstract}
The necessity of pure water is rising each day, causes are population, industrial and agricultural expansion, worldwide. Due to the increasing population of world the fresh water will become more serious problem in the coming days. Hence, people around the world have to work on different and efficient methodology to generate potable water. Solar still is one among these methods acting device. In this paper, a review of using PCM and PCM with other enhancement techniques has been discussed. Use of stearic acid as a PCM below the liner of basin, each day pure water of $9.005 \mathrm{~kg} / \mathrm{m}^{2}$ per day and $4.998 \mathrm{~kg} / \mathrm{m}^{2}$ per day has been found in the company of PCM and not including of PCM respectively. It is observed that solar desalination system in the company of paraffin- $\mathrm{CuO}$ is best among the others solar still with paraffin PCM, paraffin- $\mathrm{TiO}_{2}$, paraffin-GO. $\mathrm{CuO}, \mathrm{TiO}_{2}$ and $\mathrm{GO}$ are the nanoparticles.
\end{abstract}

Keywords: Solar Still, Phase Change Materials, energy storage, pure water.

DOI: http://dx.doi.org/10.4314/ijest.v13i1.15S

Cite this article as:

Yadav A., Khalid M.S., Saini P., Kumar A. 2021. Improvement of solar still productivity by using pcm and other enhancement technique- a review. International Journal of Engineering, Science and Technology, Vol. 13, No. 1, pp. 98-104. doi: 10.4314/ijest.v13i1.15S

Received: December 1, 2019; Accepted: February 5, 2021; Final acceptance in revised form: March 31, 2021

This paper was earlier presented at the International Conference on Energy, Environment \& Material Sciences (ICE2M), 1-3 December 2019 and substantially improved for this Special Issue. Guest Editor: Dr. Sri Niwas Singh, Professor (HAG), Department of Electrical Engineering, Indian Institute of Technology Kanpur, 208016 (U.P.) India, former Vice-Chancellor, Madan Mohan Malviya University of Technology Gorakhpur (April 2017 to July 2020).

\section{Introduction}

In agricultural and industrial sectors, the broad use of chemical plant food plays the significant role to pollute the underground water. So water drawing through the hand pump is no-more safer for drinking and cooking purposes. Due to the increasing population of world the fresh water will become more serious problem in the coming days. Hence, people around the world have to work on different and efficient methodology to generate potable water. Solar still is one among these methods acting device. Solar still device is easy to fabricate, inexpensive, easy to operate, low maintenance and need of non conventional energy. With many advantages, however, it is not famous because of its low efficiency and less output of fresh water.

Many researchers have done the tremendous works to get better efficiency and pure water of the solar still. More focus has been given on the thermal energy storage arrangement based on latent heat. Latent heat thermal energy storage arrangements are depend 
on the PCM. By giving the important kinetics, chemical and thermal physical properties, PCMs are reported and reviewed in many references [5].

\section{Review on solar still with PCM}

On the basis of modification and design many solar stills have been classified. Many researchers studied on different solar stills with phase change materials. The review on many phase change materials using in solar desalination system till 2019 is done as follows.

Table 1 Important properties of PCM [1]

\begin{tabular}{|c|c|}
\hline $\begin{array}{l}\text { Thermo dynamic } \\
\text { Characteristics }\end{array}$ & $\begin{array}{l}\text { *Enthalpy should be high. } \\
\text { *Phase changing temperature fitted to use } \\
\text { * To minimize the heat storage size latent heat should be high } \\
\text { * Latent heat of fusion should be high } \\
\text { * Melting point should be in desired temperature range } \\
\text { *Fixed and clearly mentioned freezing and melting phase change } \\
\text { temperature } \\
\text { *Density should be high } \\
\text { *D uring phase change low change of volume } \\
\text { *High thermal conductivity }\end{array}$ \\
\hline $\begin{array}{l}\text { Kinetic } \\
\text { Characteristics }\end{array}$ & $\begin{array}{l}* \text { During the freezing process no undercooling } \\
* \text { Crystallization rate is sufficient }\end{array}$ \\
\hline $\begin{array}{l}\text { Chemical } \\
\text { Characteristics }\end{array}$ & $\begin{array}{l}\text { * No chemical decomposition } \\
\text { * Non corrosive } \\
\text { *High chemical stability } \\
\text { *Non Toxic } \\
\text { *Non poisonous, non explosive and non flammable }\end{array}$ \\
\hline $\begin{array}{l}\text { Material } \\
\text { Characteristics }\end{array}$ & $\begin{array}{l}\text { * Unit size is small } \\
* \text { vapour pressure is low } \\
\text { *Phase equilibrium is favourable }\end{array}$ \\
\hline $\begin{array}{l}\text { Economical } \\
\text { Characteristics }\end{array}$ & $\begin{array}{l}\text { * Cheap } \\
\text { *Large availability }\end{array}$ \\
\hline
\end{tabular}

A.A. El-Sebaii et al [2] experimentally presented the solar still including and not including phase change material like stearic acid. It is investigated by computer simulation that daylight output reduces as the mass of stearic acid phase change material increases; but during the night and each day productivity increase with an enhance of accumulation of PCM due to the heat storage capacity of PCM. The convective heat transfer coefficient from liner of basin to water is twiced in releasing of the stearic acid; so, the coefficient of evaporative heat transfer is also improved by almost $27 \%$ with $3.3 \mathrm{~cm}$ of stearic acid below liner of the basin. Daily productivity of $9.005 \mathrm{~kg} / \mathrm{m}^{2}$ per day and $4.998 \mathrm{~kg} / \mathrm{m}^{2}$ per day has been found including PCM and with no PCM respectively on summer day. On winter days It has been studied that PCM is further proficient for lesser masses of water at basin.

Mohammad Dashtban , Farshad Farshchi Tabrizi [3] performed an experiment on weir-type cascade solar desalination system included with $18 \mathrm{~kg}$ of paraffin wax as phase change materials below the basin liner and also developed the theoretical models for solar desalination system with and with no paraffin wax. The diagram of the weir-type cascade solar desalination system is shown in fig.1.

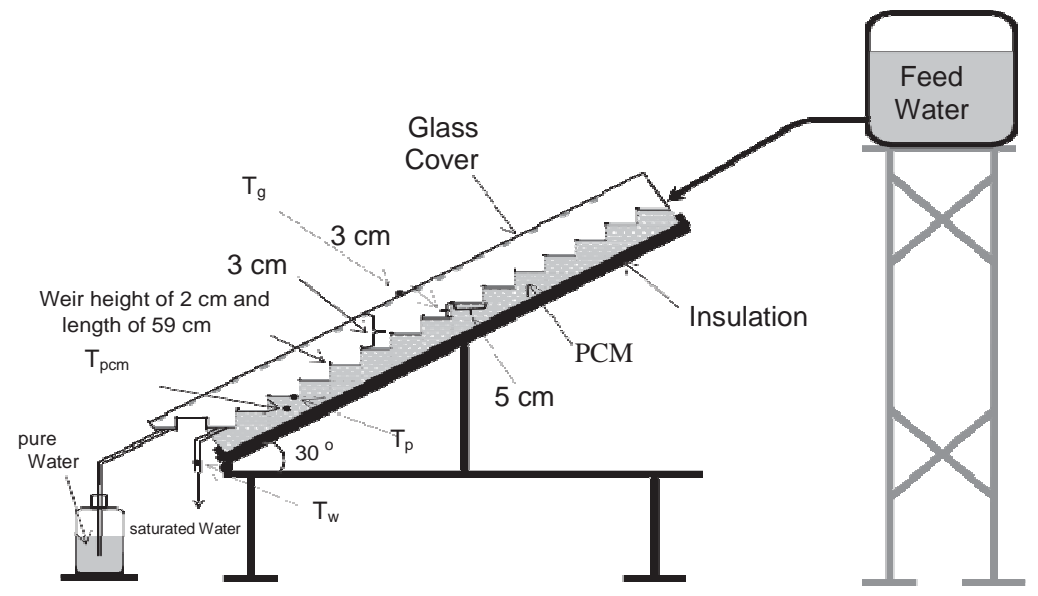




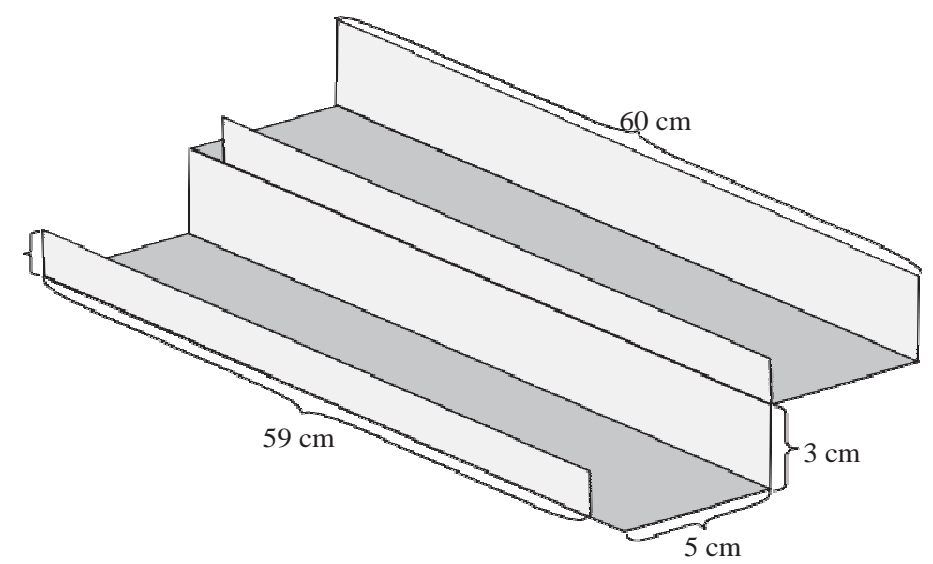

Figure 1. Schematic drawing of weir-type cascade solar Still [3].

Daily distilled water was found to be $6.7 \mathrm{~kg} / \mathrm{m}^{2}$ per day included PCM as well as $5.1 \mathrm{~kg} / \mathrm{m}^{2}$ per day with no PCM respectively. It has been shown by result that performance of solar still is increased by $31 \%$ with paraffin wax PCM on classic sunlight hours in Zahedan city of Iran.

A.E. Kabeel, Mohamed Abdelgaied [4] have also presented the experimental work on solar still including PCM and solar still not including PCM under the circumstances of Egypt. Distilled water of $7.54 \mathrm{~L} / \mathrm{m}^{2}$ per day and $4.51 \mathrm{~L} / \mathrm{m}^{2}$ per day was found for solar still including PCM and solar still not including phase change material. They also analyzed the cost for 1litre of fresh water which was 0.03 \$ for solar still including PCM and 0.032 \$ for not including PCM. They designed, fabricated and done the experimental work on the two solar still in the typical condition of Egypt. Experimental work is shown in the figs. 2 and 3.

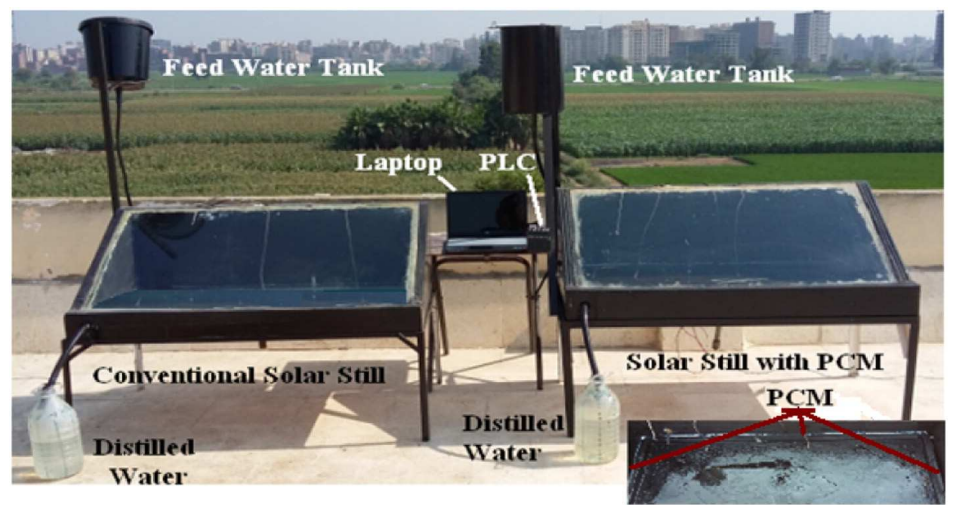

Figure 2. A photograph of the investigational set up [4]. 
(a) Conventional Solar Still

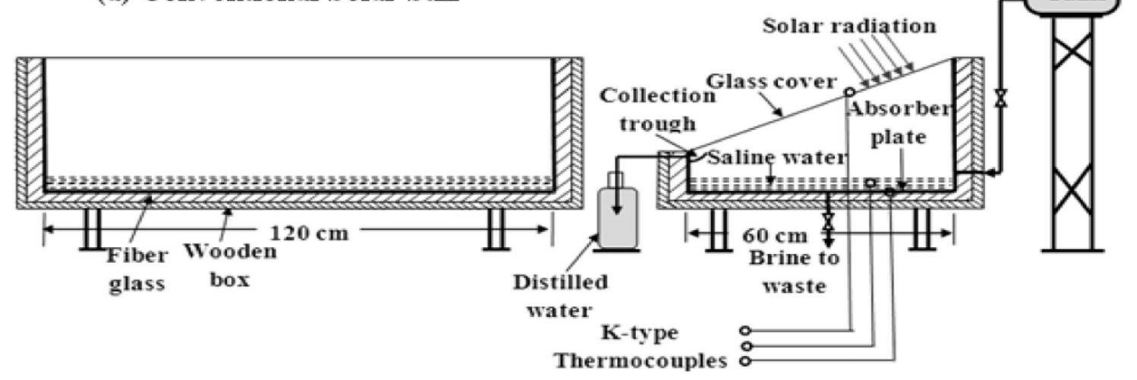

(b) Solar Still with Phase Change Material (PCM)

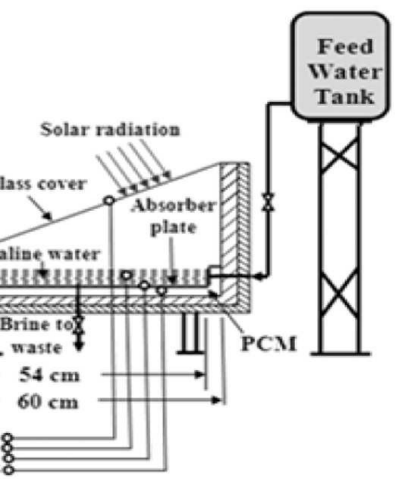

Figure 3. A graphic drawing of the experimental set up [4].

Results were discussed and also presented by graphs. It has been shown in fig. 4 that greatest temperature of basin water is $82{ }^{\circ} \mathrm{C}$ and $78^{\circ} \mathrm{C}$ for solar still using PCM and for with no PCM solar still and glass temperature is in the variety of $25-51{ }^{\circ} \mathrm{C}$ and $28-50{ }^{\circ} \mathrm{C}$ respectively.

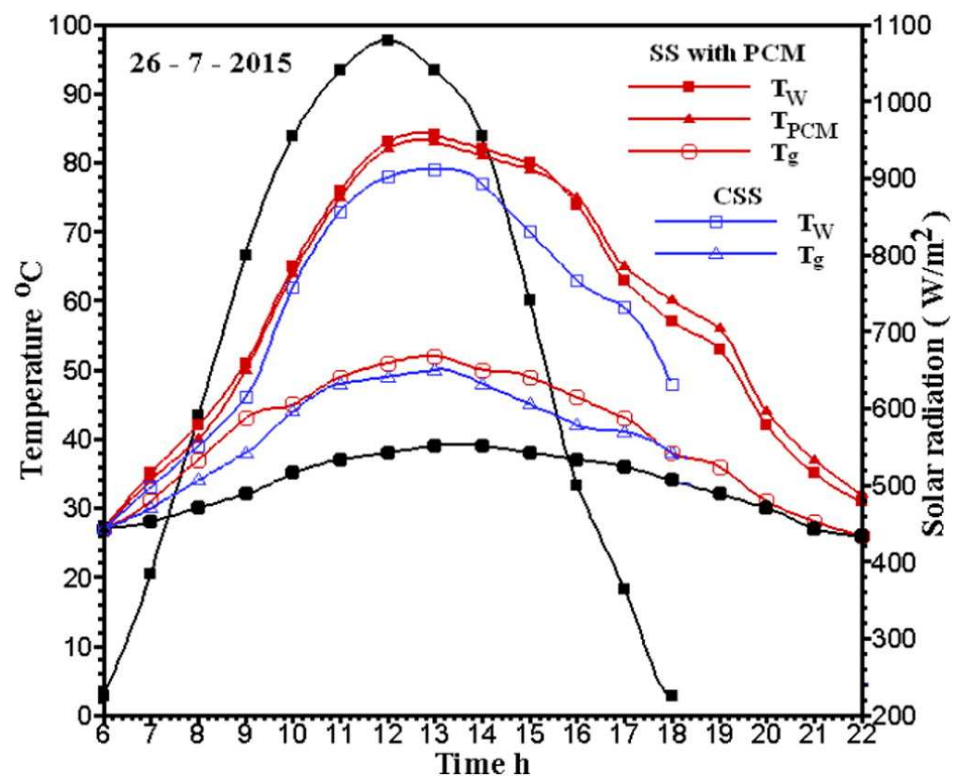

Figure 4. Hourly temperature and solar radiation for solar still using PCM and with on PCM solar still [4] 


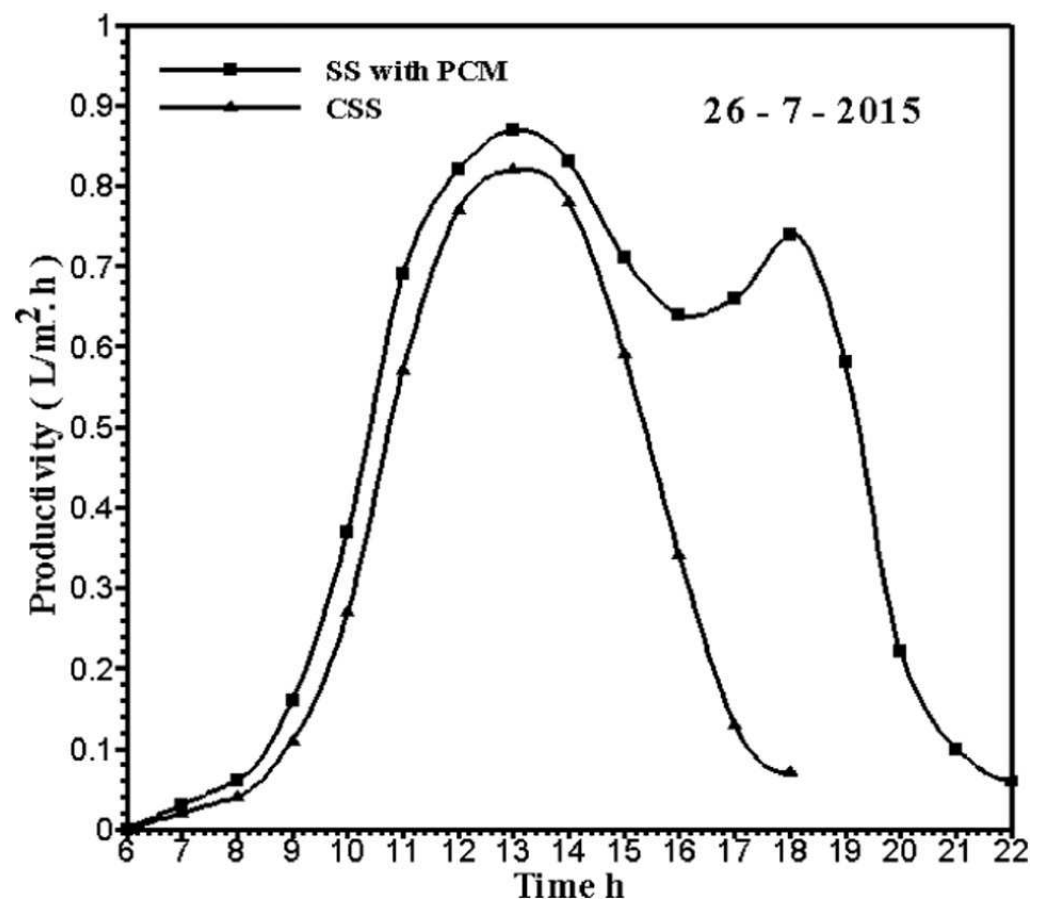

Figure 5. Deviation of hourly productivity for solar still using PCM and with on PCM solar still [4]

In fig 5 we can see the increase of hourly pure water enhancement owing to the raise of evaporation and condensation rate of water. Due to high water temperature of basin for solar still using PCM hourly pure water is superior than the usual solar still.

Mohamed Asbik et al [5] formulated and solved numerically exergy balance equation for every part of the passive solar desalination with the combination of heat storage unit using paraffin wax PCM. This work is presented in geographical conditions of Errachidia city of Morocco. They also highlighted the effect on the exergy obliteration, means entropy creation, by different effective parameters like PCM thickness, velocity of air and basin water depth. Exergy efficieny decreases and fresh water increases with latent heat storage.

A.E. Kabeel , Mohamed Abdelgaied [6] investigated by experimental work on a cylindrical parabolic concentrator using focal pipe attached with a solar desalination system in which oil heat exchanger and PCM are used to improve the water productivity. Oil heat exchanger and cylindrical parabolic concentrator works as an external source of heat to improve the water and PCM temperature. After experimental work results have been compared. It has been found that fresh water productivity is $10.77 \mathrm{Liter} / \mathrm{m}^{2}$ and $4.48 \mathrm{Liter} / \mathrm{m}^{2}$ for new solar still and usual solar still respectively. They moreover found that the price of $1 \mathrm{~L}$ of pure water reaches $0.0174 \$$ for new solar still and 0.0177 \$ for usual solar still.

S.W. Sharshir et al [7] improved the fresh water production almost $74 \%$ by implementing the three modification like using flake graphite nonoparticles, PCM and film cooling. They also presented that fresh water can be enhanced by decreasing the water deepness from $2 \mathrm{~cm}$ to $0.5 \mathrm{~cm}$ and flake graphite nonoparticles increase the temperature and vapor pressure.

Mousa Abu-Arabi et al [8] presented a conjectural form to analyse a solar still by using an outside solar collector and Sodium Thiosulfate Pentahydrate PCM and compared with experimental work. They found that productivity is reduced by using large mass of PCM and productivity can be enhanced by decreasing the overall heat transfer from $10.4 \mathrm{~W} / \mathrm{m}^{2} . \mathrm{K}$ to $2.6 \mathrm{~W} / \mathrm{m}^{2} . \mathrm{K}$. Cooling water on the cover of glass with the stream rate of $0.1 \mathrm{~kg} / \mathrm{s}$ can also increase the production.

Dsilva Winfred Rufuss D et al [9] infused three types of nanoparticles $\mathrm{TiO}_{2}, \mathrm{CuO}$ and $\mathrm{GO}$ in paraffin wax PCM. Experimental work has been done on four solar still of $0.5 \mathrm{~m}^{2}$ area of each. They compared the results on the basis of productivity and cost per liter for the four solar still. It has been found that solar still with paraffin-CuO is best as compare to solar still with paraffin PCM, paraffin- $\mathrm{TiO}_{2}$ and paraffin-GO. It provides clean water at $50 \%$ less cost of bottle water in India.

Mohamed S.Yousef, Hamdy Hassan [10] experimentally analyzed and compared the performances of solar desalination for the following five different cases at the hot climate condition of city New Borg El-Arab of Egypt. The cases are : usual solar still, solar still with PCM, hollow cylindrical pin fins used in solar desalination system with PCM, PCM and steel wool fibers in the solar still basin and using simply steel wool fibers in solar still basin. Their results presented that use of PCM effect the day time fresh water productivity negatively and overall production has good growth. Also, hollow cylindrical pin fins used in the PCM in solar still gets very good thermal performance than other cases. The case of PCM and steel wool fibers in the basin of still enhance the day time output of the fresh water of $14 \%$, infact reduction in night. The case of lone steel wool fibers in basin of solar desalination system has the maximum enhancement of daily productivity among other cases. 


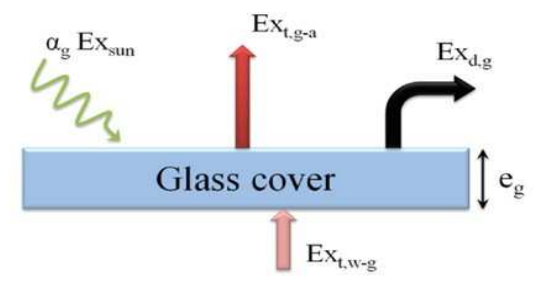

a. Exergy balance of the glass cover.

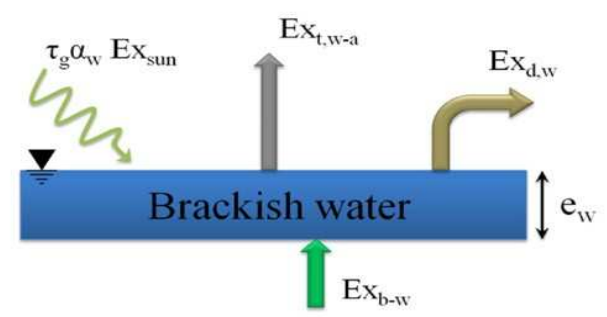

b. Exergy balance of the brackish water.

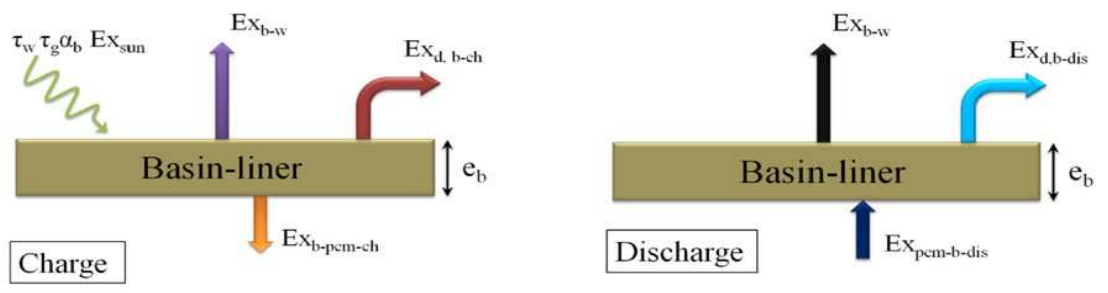

c. Exergy balance of the basin-liner (charge/discharge).
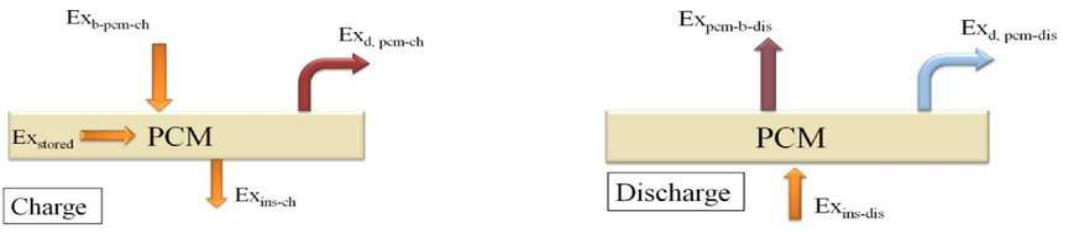

d. Exergy balance of the PCM medium (charge/discharge).

Figure 6. Exergy balances for the different part [5].

Erfan Hedayati-Mehdiabadi et al [11] investigated the exergy effectiveness of dual slope solar desalination system by using phase change material and PV/T collector in wintry weather and heat days of Zahedan city of Iran. Their results showed that the pure water production can be increase by increasing flow rate of mass from .001 to $.01 \mathrm{~kg} / \mathrm{s}$. Exergy effectiveness was lower in wintry weather days than the hot days. It was also be investigated that day time productivity decreases in day time and increases in night with the increase of mass of saline water upto $10 \mathrm{~kg}$.

\section{Conclusion}

In this review paper different types of solar still with various enhancement techniques are discussed to improve the fresh water productivity. These are listed as follows:

- The important factors which effect the distilled water production are water depth, wind intensity, solar radiation, mass flow rate, difference between water and glass temperature, glass cover inclination.

- Using flake graphite nonoparticles, PCM and film cooling, productivity can be increased.

- The fresh water production can be increase by increasing flow rate of mass from .001 to $.01 \mathrm{~kg} / \mathrm{s}$.

- $\mathrm{CuO}, \mathrm{TiO}_{2}$ and $\mathrm{GO}$ are the nanoparticles and can be used with phase change materials to enhance the pure water productivity. 
- Daily productivity has been enhanced by $56 \%$ with the use of phase change materials.

- Fresh water production is increased by PCM with oil heat exchanger.

\section{Acknowledgement}

The authors are very grateful to receive the enormous support from the department of mechanical engineering, Madan Mohan Malaviya University of Technology, Gorakhpur, Uttar Pradesh, India.

\section{References}

Shukla, A., Kant, K., \& Sharma, A. (2017). Solar still with latent heat energy storage: A review. Innovative Food Science \& Emerging Technologies, 41, 34-46. https://doi.org/10.1016/j.ifset.2017.01.004

El-Sebaii, A., Al-Ghamdi, A., Al-Hazmi, F., \& Faidah, A. (2009). Thermal performance of a single basin solar still with PCM as a storage medium. Applied Energy, 86(7-8), 1187-1195. https://doi.org/10.1016/j.apenergy.2008.10.014

Dashtban, M., \& Tabrizi, F. (2011). Thermal analysis of a weir-type cascade solar still integrated with PCM storage. Desalination, 279(1-3), 415-422. https://doi.org/10.1016/j.desal.2011.06.044

Kabeel, A., \& Abdelgaied, M. (2016). Improving the performance of solar still by using PCM as a thermal storage medium under Egyptian conditions. Desalination, 383, 22-28. https://doi.org/10.1016/j.desal.2016.01.006

Asbik, M., Ansari, O., Bah, A., Zari, N., Mimet, A., \& El-Ghetany, H. (2016). Exergy analysis of solar desalination still combined with heat storage system using phase change material (PCM). Desalination, 381, 26-37. https://doi.org/10.1016/j.desal.2015.11.031

Kabeel, A., \& Abdelgaied, M. (2017). Observational study of modified solar still coupled with oil serpentine loop from cylindrical parabolic concentrator and phase changing material under basin. Solar Energy, 144, 71-78. https://doi.org/10.1016/j.solener.2017.01.007

Sharshir, S., Peng, G., Wu, L., Essa, F., Kabeel, A., \& Yang, N. (2017). The effects of flake graphite nanoparticles, phase change material, and film cooling on the solar still performance. Applied Energy, 191, 358-366. https://doi.org/10.1016/j.apenergy.2017.01.067

Abu-Arabi, M., Al-harahsheh, M., Mousa, H., \& Alzghoul, Z. (2018). Theoretical investigation of solar desalination with solar still having phase change material and connected to a solar collector. Desalination, 448, 60-68. https://doi.org/10.1016/j.desal.2018.09.020

Dsilva W.R.D., Suganthi, L., Iniyan, S., \& Davies, P. (2018). Effects of nanoparticle-enhanced phase change material (NPCM) on solar still productivity. Journal Of Cleaner Production, 192, 9-29. https://doi.org/10.1016/j.jclepro.2018.04.201

Yousef, M., \& Hassan, H. (2019). An experimental work on the performance of single slope solar still incorporated with latent heat storage system in hot climate conditions. Journal of Cleaner Production, 209, 1396-1410. https://doi.org/10.1016/j.jclepro.2018.11.120

Hedayati M.E., Sarhaddi, F., \& Sobhnamayan, F. (2020). Exergy performance evaluation of a basin-type double-slope solar still equipped with phase-change material and PV/T collector. Renewable Energy, 145, 2409-2425. https://doi.org/10.1016/j.renene.2019.07.160

\section{Biographical notes}

Abhinav Yadav, Md Saifullah Khalid, Prashant Saini and Ankit Kumar are all of the Department of Mechanical Engineering, Madan Mohan Malaviya University of Technology (Uttar Pradesh State University) Gorakhpur, India 